\title{
Night Work and Its Health Effects: Focusing on the Relevant Laws and Regulations of the Republic of Korea
}

\author{
Won-Ju Park \\ Department of Occupational and Environmental Medicine, Chonnam National University Medical School and Chonnam National University \\ Hwasun Hospital, Hwasun, Korea
}

야간근로와 건강, 관련 법규를 중심으로 고찰

박원주

전남대학교 의과대학 화순전남대학교병원 직업환경의학과

Received December 22, 2020 Accepted February 8, 2021

Address for correspondence Won-Ju Park, MD, PhD

Department of Occupational and Environmental Medicine, Chonnam National University Hwasun Hospital, 322 Seoyang-ro,

Hwasun 58128, Korea

Tel: +82-61-379-7788

Fax: $+82-61-379-7791$

E-mail: wonjupark@jnu.ac.kr
The modern world is a 24-hour society. Night work exists for the public's convenience and interest, owing to the unstoppable nature of industries and the benefits it has for companies. Approximately $10.2-14.5 \%$ of workers in the Republic of Korea and approximately $20 \%$ of workers worldwide work at night. These workers are at an increased risk of various health problems, including sleep disorders, cerebrovascular disease, digestive system disease, metabolic syndrome, fatigue, risk of accidents, cancer, irregular menstrual cycles, depression, and mental illness. In this study, we reviewed the Korean government's legal system and guidelines to protect night workers' health. These systems include restrictions on working hours, allowances for night work, special health checkups, compensation for night work-related diseases, and active health promotion measures. Humans cannot adapt to night work completely, and social consensus and efforts are needed to reduce the burden on night workers. Current laws and regulations should be improved for night workers.

J Sleep Med 2021;18(1):1-11

\section{서 론}

현대는 하루 24시간, 1 주 7일 동안 쉬지 않고 돌아가는 24/7 사회이다. 전 세계적으로는 5 명 중 약 1 명, 우리나라에서는 전체 근로자의 10.2 14.5\%인 127 197만 명이 야간근로자 로 추정된다. ${ }^{1-3}$ 병원 · 경찰 · 소방서 · 국방과 같은 공공의 이익을 위해, 용광로 · 화학장치 · 전기가스와 같이 24시간 멈출 수 없는 장치산업을 위해, 편의점 · 숙박업 · 새벽배송 · 환경미화와 같은 국민의 편의를 위해, 때로는 회사의 최대 이익 달성을 위해 야간근로는 존재한다. 야간근로를 줄여 나 가야 한다는 사회적 합의는 이루어졌으나, 선사시대부터 순 번을 정해 야간 보초를 서고, 아픈 가족의 곁을 밤새워 지키

This is an Open Access article distributed under the terms of the Creative Commons Attribution Non-Commercial License (https://creativecommons.org/licenses/by-nc/4.0) which permits unrestricted non-commercial use, distribution, and reproduction in any medium, provided the original work is properly cited.
던 인간의 특성상 야간근로는 영원히 존재할 것이다.

의료계의 야간근로 또한 사라질 수 없는 영역이며, 임상의 사들에게 야간근로는 너무나 익숙한 친구이다. 의사들은 야 간근로가 인체에 미치는 영향과 치료와 같은 의학적 지식에 대해서는 박식하나, 야간근로에 대한 사회적 합의 수준과 그 에 따라 도출된 법률적 규정에는 무관심한 경우가 있다. 그 리고 살인적인 야간근로를 소명으로 살아온 의사들에게 사 회적 합의 수준은 평소 본인이 느껴왔던 체감과는 크게 동떨 어져 보일 수 있다. '우리나라에서 법적으로 야간근로를 하기 위해서는 우선 무엇이 충족되어야 하는가? 야간근로를 도대 체 얼마나 할 수 있는가? 야간근로를 너무 많이 하면 어떤 문 제가 발생하는가? 야간근로를 너무 많이 해 병이 생긴 환자 에게 무엇을 해줄 수 있는가?'라는 물음을 우리나라의 법률 규정에 근거하여 살펴보고자 한다. 교대근무와 야간근로는 서로 교집합이 큰 밀접한 관계의 근무형태이다. 따라서 본 
종설에서는 교대근무, 야간근로와 야간작업이라는 용어를 상황에 맞게 혼용하여 사용하였다. 법률 규정을 살펴보기 전 에 그러한 법률 제정의 근거가 된 야간근로의 건강영향에 대해 우선 검토하였다.

\section{본 론}

\section{야간근로의 건강영향}

인간은 자연스러운 일주기 생체리듬(circadian rhythm)에 따라 생리적, 정신적 기능을 수행한다. 이러한 생체리듬은 외 적인 시계인 빛의 자극과 내적인 생체시계(biologic clock)의 조화를 통해 조절된다. 야간근로와 교대근무는 식사, 기상과 잠드는 시간과 같이 조화로운 인간의 활동을 변화시키며, 이 러한 변화에 부적응하게 되는 경우 다양한 건강문제(shift work maladaptation syndrome)가 발생하게 된다. ${ }^{4}$

\section{뇌심혈관질환}

야간근로는 혈압의 상승을 유발하고 휴식을 취하더라도 혈압의 하강이 제대로 이루어지지 않아 뇌심혈관계에 만성 적인 부담요인이 된다. 34개의 연구, 총 2,011,935명의 연구 대상자를 포함시킨 메타분석 결과 교대근무는 심근경색의 상대위험도를 1.23[95\% confidence interval(CI): 1.15 1.31], 관상동맥질환은 $1.24(95 \% \mathrm{CI}: 1.10 \sim 1.39)$, 뇌경색은 $1.05(95 \%$ CI: 1.01 1.09)로 증가시켰다. 교대근무의 질병 기여위험도는 심근경색의 경우 전체의 $7 \%$, 관상동맥질환의 $7.3 \%$, 뇌경색의 $1.6 \%$ 를 차지하였다. ${ }^{5}$ 동일 회사에서 같은 업무를 수행하는 근로자를 대상으로 관상동맥 CT 혈관촬영술을 시행한 연구 에서 야간교대근로자가 비교대주간근로자에 비해 관상동맥 경화반(coronary plaque)의 관찰 교차비가 2.92(95\% CI: 1.02 8.33)로 상승하여 동맥경화의 위험인자임을 확인할 수 있었다. ${ }^{6}$

80,108 명의 미국 여성 간호사를 대상으로 한 연구에서 야 간교대근무를 시행한 기간이 5년씩 길어질수록 허혈성 뇌졸 중의 위험비가 $1.04(95 \% \mathrm{CI}: 1.01$ 1.07)씩 증가하는 것으로 조사되었다. ${ }^{7}$ 개의 코호트 연구를 메타분석한 결과 교대근 무자들은 비교대근무자에 비해 뇌졸중 사망률의 비교위험 도가 1.03(95\% CI: 1.00 1.07)으로 경계치 수준으로 증가하 였다. ${ }^{8}$ 뇌혈관질환은 심혈관질환의 연구에 비해 야간근로와 의 연관성에 관한 유의한 결과가 상대적으로 적으나, 뇌혈관 질환과 심혈관질환의 위험요인은 일치하는 부분이 많다. 따 라서 야간근로자의 건강보호를 위해 뇌심혈관질환 위험요 인을 동시에 관리하는 것이 좋을 것으로 판단된다.

\section{당뇨병}

야간근로와 교대근무는 당뇨병 발생과 악화의 위험을 증 가시킨다. 메타분석 연구 결과 교대근무자는 당뇨병의 교차 비가 1.09(95\% CI: 1.05 1.12)로 증가하는 것으로 분석되었 고, 특히 이러한 연관성은 여성보다 남성에서 교차비 1.37 (95\% CI: 1.20 1.56)로 더 높은 것으로 나타났다. ${ }^{9}$ 여성간호 사 연구에서도 교대근무의 기간이 길어질수록 2형 당뇨병 발생의 위험비가 증가하여 교대근무를 1 2년 수행한 경우 1.05(95\% CI: 1.00 1.11), 3 9년 수행한 경우 1.20(95\% CI: 1.14 1.26), 10 19년 수행한 경우 1.40(95\% CI: 1.30 1.51), 그리고 20년 이상 수행한 경우 $1.58(95 \%$ CI: 1.43 1.74)로 노 출에 비례하여 유의하게 증가하였다. ${ }^{10}$ 야간교대근무는 음주 를 유발하고 식사의 질을 떨어뜨리며 규칙적인 식생활 습관 을 방해하게 된다. 또한, 인슐린의 분비에 영향을 미치며 당 뇨병 약물 복용에 어려움을 주어 당뇨병이 유발 또는 악화 되는 것으로 판단된다. ${ }^{11}$

\section{대사증후군}

야간근로와 대사증후군의 관련성에 대한 13 개의 연구를 메 타분석한 연구 결과 통합 상대위험도는 $1.57(95 \%$ CI: 1.24 1.98)로 평가되었다. 10년 이상 장기간 야간근로를 수행한 경 우 상대위험도는 $1.77(95 \% \mathrm{CI}: 1.32$ 2.36)로 보다 증가하였 으며, 남성의 상대위험도 $1.36(95 \% \mathrm{CI}: 1.03$ 1.81)보다는 여 성 상대위험도 $1.61(95 \% \mathrm{CI}: 1.10$ 2.34)로 여성에서 더 증가 하는 것으로 나타났다. ${ }^{12}$ 야간근로를 수행하는 남녀간호사를 4년간 추적한 연구에서 연간 대사증후군 발생률 평균은 2.9\% 로, 주간근무만 수행하는 남녀간호사의 발생률 $0.5 \%$ 에 비해 상대위험도 5.0(95\% CI: 2.1 14.6)으로 증가하는 것으로 나 타났다. ${ }^{13}$

\section{비 만}

28개의 연구를 메타분석한 결과 야간근로는 비만과 과체 중의 교차비를 $1.23(95 \% \mathrm{CI}: 1.17$ 1.29)으로 유의하게 증가 시켰으며, 특히 복부비만의 위험도를 더욱 증가시키는 것으 로 분석되었다. ${ }^{14}$ 운동부족, 폭식, 불규칙한 식사, 야간시간대 의 질 낮은 음식과 음주 등 야간근로로 인한 나쁜 생활습관과 수면에 대한 생리적 부적응의 결과로 비만의 위험도가 증가 하는 것이다. ${ }^{15}$

\section{사고 및 생산성 저하}

야간근로는 피로 증가와 수면장애를 유발한다. 이는 근무 중 주의력을 감소시켜 생산성을 저하하고, 더 나아가 업무상 사고의 위험을 유의하게 증가시킨다. ${ }^{16}$ 야간근로자가 의도치 
않게 근무 중 졸음에 빠질 교차비가 1.6(95\% CI: 1.14 2.23) 으로 유의하게 증가하였다. ${ }^{17}$ 이러한 근무 중 졸음과 피로는 사업장의 치명적인 사고의 위험성을 높인다. 특히 원자력 발 전소, 대형차 운전, 선박과 항공 관련 업무 및 중장비 관련 종사자 등의 주의력 감소와 졸음은 대형사고로 이어져 본인 뿐만 아니라 동료와 공공에 큰 해를 끼치게 된다. ${ }^{18}$ 근로자 47,860 명을 20년간 추적관찰한 연구에서 지난 2주간 수면장 애가 있었던 경우 치명적인 산업재해의 비교위험도가 1.89 (95\% CI: 1.22 2.94)로 증가하여, 야간근로를 직장에서의 사 고로 인한 사망의 위험인자로 제시하였다. ${ }^{19} 110,236$ 개의 직 업기록과 13 년간 82,000 인년의 직업내용을 분석한 미국의 국가 종단면조사(National Longitudinal Survey of Youth) 에 따르면 일반적인 주간근로자에 비해 야간교대근무자는 직업성 부상과 질병의 위험비가 $1.30(95 \%$ CI: 1.12 1.52)으 로 유의하게 증가하였다..$^{20}$ 뉴질랜드의 헌혈자 건강연구에 따 르면 야간근로를 포함한 교대근무자는 직장 내에서 부상의 상대위험도가 $1.90(95 \%$ CI: 1.50 2.40)으로 유의하게 증가 하였다. ${ }^{21}$ 캐나다 근로자를 대상으로 한 연구에서도 야간근 로는 업무상 상해의 교차비를 여성에서 2.04(95\% CI: 1.13 3.69), 남성에서 1.91(95\% CI: 1.21 3.03)로 각각 증가시키며, 야간근로는 여성의 경우 업무상 상해의 초과 위험도를 $14.4 \%$, 남성에서는 $8.2 \%$ 증가시키는 것으로 분석되었다. ${ }^{22}$ 또한, 야 간교대근무에 장시간근로가 복합되는 경우와 연속적인 야 간근로는 사고의 위험도를 보다 상승시킨다. 여러 연구를 검 토한 결과 야간교대근무와 장시간근로가 복합되는 경우 사 고의 위험도를 50 100\% 증가시키는 것으로 일관되게 나타 났다. ${ }^{23}$ 밤을 새우며 퇴근하지 않고 환자를 돌보는 의료진이 결코 미덕만이 될 수 없는 이유이다.

야간근로는 사업장 안에서뿐만 아니라 밖에서의 사고위험 도 증가시킨다. 졸음운전으로 인해 출퇴근 사고 발생 위험이 증가한다. 업무 중 졸음에 의도적 또는 비의도적으로 빠지는 경우보다, 억지로 깨어 졸음을 내쫓으며 업무를 수행한 경우 사고의 위험이 더욱 증가하게 된다. 24,25 「산업재해보상보험법 제 37 조(업무상 재해의 인정 기준)」의 개정에 따라 사업주가 제공하는 교통수단이 아니더라도 2016년 9월 29일 이후 통 상적인 출퇴근 중 발생한 사고는 업무상 재해로 인정하고 있 다. 사업주가 사업장 안뿐만 아니라, 근로자가 회사로 출근하 고 집으로 복귀하는 과정까지도 세심히 배려해야 하는 이유 이다. 사업장에서 야간근로자에게 적절한 사이잠(napping)을 제공하는 것이 사고를 예방하는 데 효과적일 것이다. ${ }^{26}$

\section{소화기계질환}

소화효소는 일정한 일주기에 맞춰서 규칙적으로 분비되어
야 하나, 야간교대근무자는 내인성 일주기가 외부환경과 불 일치되어, 소화효소 분비에 문제가 발생하게 된다. 또한 야 간근로자는 커피, 간식과 술에 의존하는 경향이 높아지게 되 며, 식사시간과 식사의 질이 떨어져 소화기계 질환과 증상의 발생이 증가하게 된다. 20 개의 연구를 메타분석한 결과에 따 르면 야간교대근무는 소화불량, 속쓰림과 같은 위장관 증상, 소화성 궤양과 기능성 위장관 질환과 유의한 연관성을 보였 다. ${ }^{27}$ 일본인을 대상으로 한 연구에서 일반 주간근무자의 위 궤양과 십이지장궤양의 유병률이 각각 $1.03 \%, 0.69 \%$ 인 것에 비해 교대근무자는 $2.38 \%, 1.37 \%$ 로 위궤양은 2.31 배, 십이지 장궤양은 1.99 배 증가하였다. ${ }^{28}$ 미국의 간호사를 대상으로 한 연구에서 과민성장증후군의 경우 주간근무 간호사의 유병률 $31 \%$ 에 비해, 교대근무 간호사는 $48 \%$ 로 통계적으로 유의하 게 증가하였다. 기능성 변비, 설사와 복통의 유병률도 교대 근무 간호사에서 유의하게 증가하였다. ${ }^{29}$ 우리나라 6,040 명의 조선소 남성 근로자를 대상으로 내시경 검사결과를 단면조 사한 연구에서 야간근로자는 주간근로자에 비해 식도염의 교차비가 $1.41\left(95 \%\right.$ CI: 1.03 1.94)로 상승하였다..$^{30}$ 야간교대 근무는 헬리코박터 파일로리에 대한 위장점막의 방어기전을 약화시켜 위염과 위궤양의 위험도를 높인다. 헬리코박터 파 일로리에 동일하게 감염되었다고 하더라도 야간교대근무자 는 주간근무자보다 십이지장궤양 유병률의 교차비가 3.96 (95\% CI: 2.10 7.47)로 증가하였다. ${ }^{31}$

\section{수면장애와 피로}

야간근로로 인한 다양한 건강문제 중 가장 직접적이고 큰 문제는 수면장애이다(shift work sleep disorder). ${ }^{32}$ 야간근로 에 적응하지 못한 근로자들은 자신의 일주기리듬과 맞지 않 는 시간대에 깨어 근무를 하게 된다. 이는 필연적으로 일주 기리듬과 수면각성 패턴에 방해를 일으키며, 이로 인해 수면 장애가 발생하게 된다. 야간근로 후 낮시간대의 수면은 밤시 간대보다 숙면을 방해하는 소음과 빛에 빈번히 노출되게 된 다. ${ }^{33,34}$ 야간교대근무자들은 수면의 질뿐만 아니라 양 또한 줄 어드는 경향을 보인다. ${ }^{35,36}$ 야간근로 후 수면은 최대 2 시간까 지 감소하는 것으로 조사되었으며 주로 렘(rapid eye movement)과 2단계 수면이 감소하게 된다. ${ }^{32}$ 수면무호흡증이 있 는 31 명의 야간교대근무자와 10 명의 주간근무자의 수면다 원검사 결과를 비교한 연구에서 야간교대근무자는 무호흡저호흡지수(apnea-hypopnea index)와 산소불포화지수(oxygen desaturation index)의 유의한 악화를 보여 심한 수면무 호흡증 환자에서는 야간근로를 제한시키는 것을 권고하였 다. ${ }^{37}$ 이러한 수면의 질과 양의 감소는 깨어 있어야 하는 활 동 시간대에 과도한 졸음과 피로로 이어지며, 수면을 취해야 
하는 시간대의 불면을 유발하게 된다. ${ }^{32}$ 수면장애는 사고, 뇌 심혈관질환, 우울증, 정신질환과 월경이상 등, 야간근로의 다른 건강영향 발생과의 연결고리가 된다. 따라서 야간근로 자 보건관리에서 수면문제 해결이 핵심 방안이 될 것으로 판 단된다.

\section{암}

전 세계적인 암연구결과들을 수집하여 발암성을 결정하는 대표적인 기관은 프랑스 리옹에 위치한 국제암연구소(International Agency for Research on Cancer)이다. 2007년 12월 5 일 국제암연구소에서는 교대근무를 2군 발암물질인 인간에 게서 발암 추정 물질로 분류하였다(Group 2A, probably carcinogenic to humans). ${ }^{3}$ 교대근무로 인한 일주기 생체리듬 방 해가 암을 발생시키는 증거가 어느정도 확보되었다는 것이 다. 야간근로로 인한 멜라토닌 분비 억제, 면역 억제, 만성 염 증, 세포증식과 여성에서 에스트로겐 항상성 등이 암발생의 중요한 기전으로 작용하는 것으로 나타났다. ${ }^{3}$ 암종에서는 유 방암과의 관련성이 높은 것으로 확인되었으며, 여러 체계적 인 리뷰와 메타분석에서 연구간에 차이는 있으나 야간근로의 경험이 있는 경우 유방암의 상대 위험도가 1.21 1.91배 증 가하는 것으로 확인되었으며, 야간근무 경력이 5년씩 증가 할 때마다 유방암의 발생 위험이 약 $3 \%$ 씩 증가하였다. ${ }^{38,39}$ 6,093명의 유방암 사례를 대조군과 비교한 연구에서 야간근 로경험이 있는 경우, 없는 경우에 비해 유방암의 교차비가 $1.12(95 \%$ CI: 1.00 1.25)로 증가하였다. 폐경기 전 여성으로 층화 후 분석에서는 $1.26(95 \% \mathrm{CI}: 1.06$ 1.51), 주당 10시간 이상의 야간근로를 하는 경우에는 $1.36(95 \% \mathrm{CI}: 1.07 \sim 1.74)$, 주당 3일 이상의 야간근로를 하는 경우에는 $1.80(95 \% \mathrm{CI}$ : 1.20 2.71), 주당 3 일 이상의 야간근로를 10 년 이상 수행한 경우 2.55(95\% CI: 1.03 6.30)로 교차비가 증가하였다. 유방 암과 야간근로는 양적 상관관계를 보였으며, 최근 또는 현재 까지 야간근로를 수행하는 경우와 폐경 전 여성에서 더욱 위 험성이 높은 것으로 나타났다. ${ }^{40}$

유방암 외에도 야간근로와 전립선암, 대장암, 직장암의 관 련성에 대한 많은 연구가 있었고, 국제암연구소는 2019년 6월 전문가집단 토의 후 이 세 가지 암종을 Group $2 \mathrm{~A}$ 로 격상하여 분류하기로 결정하였다. ${ }^{3,41}$ 캐나다의 남성 연구에서 야간근 로의 경험이 있는 근로자는, 경험이 없는 근로자에 비해 전립 선암의 교차비는 2.77(95\% CI: 1.96 3.92), 대장암은 2.03(95\% CI: 1.43 2.89), 직장암은 2.27(95\% CI: 1.24 4.15)로 유의하 게 증가하였다. ${ }^{42}$ 여성간호사 190,810 명을 24년간 추적조사한 코호트 연구에서 15년 이상 야간근로를 한 경우 직장암의 위 험비가 $1.60\left(95 \%\right.$ CI: 1.09 2.34)으로 유의하게 증가하였다. ${ }^{43}$
야간근로와 대장암 위험의 상관관계를 평가하기 위한 메타 분석 결과 야간근로는 대장암의 교차비를 $1.32(95 \% \mathrm{CI}$ : 1.21 1.55)로 증가시켰으며, 야간근로 수행기간이 5년씩 길 어질수록 교차비는 1.11(95\% CI: 1.03 1.20)씩 유의하게 증 가하는 것으로 나타났다. ${ }^{44}$

\section{우울증, 기분장애 및 자살}

근무환경은 근로자의 단기적인 기분 변화와 장기적인 정 신건강에 중요한 영향을 미치는 중요한 인자이다. 특히, 야 간근로로 인한 수면장애는 우울증, 기분장애와 자살 경향성 의 악화와 밀접한 관련이 있으며, 야간근로 시간과 기간이 길 어질수록 위험도는 증가하게 된다..$^{45-47}$ 야간근로자는 가정 및 사회생활과 일정 부분 단절되게 되며, 이로 인해 사회적 지지의 부족이 발생하게 된다. 이와 함께 야간근로로 인한 수면장애와 같은 건강 문제, 멜라토닌 분비 장애, 비타민D 합성 장애와 같은 건강문제가 동반되게 된다. 야간근로자는 우울증 및 불안 관련 척도의 지수가 높으며 이로 인해 수면제 와 같은 약물 복용의 위험도가 커진다. ${ }^{48}$ 남성에서 4 년 이상 야간근로를 수행한 경우, 일반 정신건강 척도(General Health Questionnaire) 설문점수 상의 불안의 교차비는 2.58(95\% CI: $1.22 ~ 5.48)$, 우울증의 교차비는 6.08(95\% CI: 2.06 17.92) 로 증가하였다. 여성에서는 불안의 교차비는 2.58(95\% CI: 1.53 4.35), 우울증의 교차비는 4.17(95\% CI: 1.45 11.98)로 증가하였으며, 여성의 경우 교대근무 패턴에 더 민감한 영향 을 받았다. 여성에 있어 불규칙한 교대근무 패턴은 가정과 일의 양립에 어려움을 주고 이로 인해 정신적 스트레스가 더 발생될 것으로 추측되었다. ${ }^{49}$ 대만의 여성간호사를 대상으로 한 연구에서도 교대근무 간호사들이 비교대근무자에 비해 피 츠버그 수면의 질 평가(Pittsburgh Sleep Quality Index, PSQI) 상 수면의 질이 좋지 않을 교차비가 2.26(95\% CI: 1.57 3.28) 이었으며, 동반되어 시행한 건강척도(Chinese Health Questionnaire-12) 평가 상 정신건강이 좋지 않을 교차비가 1.91 (95\% CI: 1.39 2.63)로 유의하게 증가하였다. ${ }^{50}$

\section{월경주기 불규칙과 여성 건강}

야간교대근무를 처음 실시하는 신규 여성간호사를 대상으 로 한 연구에서 근무 시작 후 6개월 시점 조사에서 근무에 적응하지 못하고 불면증과 같은 수면장애가 발생한 그룹의 경우, 1 년 뒤 재추적관찰한 결과 불규칙한 월경주기 유병률 의 교차비는 3.05(95\% CI: 1.81 5.13), 발생률의 교차비는 2.05(95\% CI: 1.12 3.77)로 유의하게 증가하였다. ${ }^{51}$ 야간근 로는 특히 가임기 여성에게 상대적으로 큰 위험을 초래한다. 월경주기 불규칙 또는 중단, 자연 유산, 저체중 출산과 조산 
의 위험을 높이는 것으로 알려져 있다. ${ }^{32}$

\section{야간근로의 법적관리}

\section{야간근로 및 교대근무의 정의}

국제노동기구(International Labour Organization)에 따 르면 야간근로란 자정부터 오전 5시까지의 시간을 포함하여 연속 7시간 이상 동안 수행하는 작업을 의미하며 사용자 및 근로자 단체의 협의 후 해당 국가 또는 행정당국이 최종결 정한다고 기술되어 있다. ${ }^{52}$ 우리나라에서는 「근로기준법 제 56 조(연장, 야간 및 휴일 근로)에 따라 오후 10시부터 오전 6시까지의 근로를 야간근로로 정의하고 있다. 고용노동부의 「교대제 근로자 근로기준법 적용지침」에 따르면 교대제근로 란 근로자를 둘 이상의 조로 나누어 근로하게 하는 제도로, 일반적으로 보통의 주간근무에서 벗어나 동일한 업무를 실 시하는 근로자가 2개 이상의 팀으로 돌아가며 정해진 일정 에 맞춰 근무를 번갈아 하는 제도이다. 예를 들어 24시간 가 동하는 사업장에서의 2조 2교대는 근로자가 2개의 팀으로 나누어져 있으며 하루 24시간의 업무를 12시간씩 2교대로 실시하고, 4조 3교대는 근로자가 4개의 팀으로 나누어져 있 으며, 하루 24시간의 업무를 8시간씩 3교대로 실시하고 한 조는 비번이 되는 형태이다. 교대제의 형태는 매우 다양하 다. 공공의 안전을 위해 경찰과 소방공무원에서 실시하는 교 대제들은 다음과 같이 다양하며, 지역 및 관할 특성에 따라 선택하게 된다. 24시간 일하고 24시간 쉬는 격일제(24시간 맞교대), 3주기(24시간 당번, 비번, 비번), 6주기(주간, 주간, 야간, 야간, 비번, 비번), 7주기(주간, 주간, 주간, 야간, 비번, 야간, 비번), 9주기(주간, 주간, 주간, 야간, 비번, 야간, 비번, 야간, 비번), 21 주기(주간, 주간, 주간, 주간, 주간, 비번, 비번, 야간, 비번, 야간, 비번, 야간, 비번, 24시간 당번, 비번, 야간, 비번, 야간, 비번, 24시간 당번, 비번) 등이 있다. 교대제 종 류, 교대하는 시점, 각 교대의 근무시간과 교대제 방향 등은 각 사업장의 특성에 따라 다르며 적절한 교대근무제 설계는 각 사업장의 경쟁력과 직결되는 사항이다. 현재 각각의 사업 장에서 적합한 교대제를 도입하기 위해 다양한 시도가 이루 어지고 있으며 모범 성공사례들도 소개되고 있으니, 적극적 인 벤치마킹이 요구된다. 정부에서도 교대제 개선을 통한 고 용창출과 기업경쟁력 강화를 위하여 컨설팅서비스나 지원 금제도와 같은 다양한 사업을 진행하고 있다.

\section{야간근로와 근로시간}

2018년 2월 28일, 근로기준법 개정이 국회를 통과하여 주당 가능한 근로시간이 68 시간에서 52시간으로 단축되었다. 개
정된 「근로기준법 제50조(근로시간)와 제53조(연장근로의 제한)」에 따르면 일반적인 우리나라 근로자는 법정 근로시간 40 시간과 연장근로시간 12 시간을 더하여, 주당 최대로 근로 가 가능한 시간은 52 시간이 되었다. 상시 30 명 미만의 근로 자가 고용된 소규모 사업장에서는 52시간에 추가로 8시간을 더 연장할 수 있으며, 「근로기준법 제59조(근로시간 및 휴게 시간의 특례)」에 따른 특례업종(보건업, 육상운송 및 파이프 라인 운송업, 수상운송업, 항공운송업, 기타 운송관련 서비 스업)은 52시간에 추가로 연장근로가 가능하며 상한은 따로 정해 놓지 않았다. 또한「근로기준법 시행규칙 제9조(특별한 사정이 있는 경우의 근로시간 연장 신청 등)」에 따르면 재난, 사고, 인명보호, 장애, 고장이나 사업에 중대한 지장 또는 손 해가 초래되는 경우 특별연장근로가 가능하다. 우리나라 노 동법상 야간근로에 대한 특별한 시간제한 규정은 없으므로 최대 근로시간 내에서 야간근로가 가능하여, 고정적으로 야 간근로만 장시간 수행하는 직업군이 존재하고 있다. 다만 야 간근로로 인한 건강영향에 보다 취약한 여성, 임산부와 미성 년자를 보호하고자 하는 법적규제는 존재한다.

「근로기준법 제70조(야간근로와 휴일근로의 제한)」에 따 르면 18세 이상의 여성을 오후 10시부터 오전 6시까지의 시 간에 근로를 시키려면 그 근로자의 동의를 받아야 한다. 임 산부, 산후 1년 미만의 여성과 18세 미만의 연소근로자는 야 간근로에 대한 기준이 보다 엄격하다. 임산부의 경우 해당 여성이 명시적으로 청구하고 사업장의 근로자대표와 협의 후 고용노동부장관의 인가를 받아야 한다. 산후 1 년 미만의 여성과 연소근로자는 동의를 받고 사업장의 근로자대표와 협의 후 고용노동부장관의 인가를 받아야 한다. 이렇듯 한국 에서 야간근로에 대한 제한은 여성과 연소자에 대한 규정이 전부이다. 수면박탈은 정상적인 성장호르몬 분비에 영향을 미치므로 성장중인 미성년자, 태아를 임신하거나 가임기의 여성을 보호하는 것은 의학적으로 합리적이다. ${ }^{53}$ 다만 미성 년자와 여성이 아니더라도 야간근로는 필연적으로 근로자의 건강 및 삶의 질 저하를 유발하므로 야간근로의 남용을 막고 근로자의 건강을 유지하기 위한 정부의 대책이 필요하다. 이 러한 대책들 중에는 야간근로수당과 야간작업 특수건강진 단제도가 있다.

\section{야간근로수당}

「근로기준법 제 56 조(연장, 야간 및 휴일근로)」에 따르면 사 용자는 오후 10 시부터 오전 6시 사이에 근로자에게 일을 시 키기 위해서는 약정한 통상임금에 $50 \%$ 를 가산한 야간근로 수당을 지급해야 한다. 야간근로가 휴일에 발생하였거나, 연 장근로시간에 발생했다면 휴일근로수당 $50 \%$ 가산과, 연장 
근로수당 $50 \%$ 가산이 중복되어 할증임금을 지불하게 된다. 이 제도는 야간에 근로자에게 일을 시키기 위해서 사업주는 임금비용 지출이 대폭 증가하게 되고, 더불어 사고와 근로자 질병에 대한 책임의 범위가 커지게 되므로 불필요한 야간근 로가 감소하게 되는 효과가 있다. 다만 의료계에서 의사직을 중심으로 만연한 온콜제도와 같은 야간호출대기는 현재 법 정 근로시간으로 인정받지 못해 제대로 된 수당을 받지 못 하고 있다. 야간호출대기 상태의 업무 강도가 본래 수행하는 업무에 비해 상당히 낮기 때문에 통상의 근로로 볼 수 없다 는 것이 그 이유이다. 하지만 밤새 연락선상에 대기하다 호출 을 받으면 단시간내에 환자에게 복귀해야 하며, 연락을 받지 못하거나 늦게 복귀했을 때의 책임문제 발생 등 호출대기시 간은 심각한 스트레스를 유발해 제대로 된 휴식을 취할 수 없게 한다. 과로로 인한 뇌심혈관질환의 업무상질병 판정 과 정에서도 야간호출대기시간은 근로시간으로 현재 인정받지 못한다. 장기간 야간호출대기를 하며 근로자가 받은 스트레 스와 개인의 활동영역에 지대한 제한을 주어 근로자의 삶에 큰 기회비용을 발생하게 한 것을 고려하면 이것은 상당히 불 합리한 것으로 판단된다. 이러한 비보상적 야간호출대기는 워라밸(work and life balance)과 워크 다이어트(work diet) 를 지향하는 현대사회에 역행하는 제도이며, 근로기준법의 휴식시간 등의 규정과도 상충되므로 향후 야간호출대기에 대한 명문화와 합리적인 수당 시스템이 반드시 필요하다.

\section{야간작업 특수건강진단}

과로사는 일본말 가로시(karoshi)에서 유래되었으며 직업 적으로 야간근로, 장시간근로 및 정신적 스트레스 등 다양 한 직무스트레스에 의해 근로자가 사망에 이르게 되는 것으 로 주로 뇌심혈관질환과 자살사망을 말한다. 우리나라에서 도 뇌심혈관질환의 업무상질병 사망자 수는 2013년 248명, 2014년 318명, 2015년 293명, 2016년 300명, 2017년 354명, 2018년 457명으로 꾸준히 증가하는 추세이다. ${ }^{54}$ 뇌심혈관질환 의 업무상재해 승인율도 2014년 22.6\%, 2015년 23.5\%, 2016년 $22.0 \%, 2017$ 년 32.6\%로 증가하고 있다. ${ }^{55}$ 과로사의 인정건수 증가는 과거에 비해 작업환경의 악화라고 볼 수는 없으며, 사 회적으로 산업재해를 바라보는 인식이 바뀌었고, 고령 근로 자의 비중이 늘고 있으며, 많은 연구결과들을 통해 인정기준 이 차츰 완화된 데 이유가 있다. 이유를 불문하고 국가는 과 로로 사망하거나 장애를 얻게 되는 근로자의 수를 감소시킬 의무가 있으며, 이를 위한 가장 중요한 정책으로는 주 52시간 근무제와 야간근로자를 대상으로 한 특수건강진단제도 도 입이 있겠다.

특수건강진단은 산업안전보건법에 따라 정해진 유해물질
을 취급하는 근로자에 대해서 직업병 선별과 사후관리를 위 해 의무적으로 주기적인 건강검진을 받도록 하는 제도이다. 이러한 특수건강진단은 의사면허 취득 후 4년간 직업병에 대한 수련을 끝마친 직업환경의학 전문의를 통해 실시되고 있다. 유해물질로는 109종의 유기화합물, 20 종의 금속류, 8 종의 산 및 알칼리류, 14 종의 가스상 물질, 12 종의 허가대상 물질, 7종의 분진, 8 종의 물리적인자, 금속가공유가 있으며 2014년 야간작업이 특수건강진단 대상 유해인자로 새로 지 정되었다. 300인 이상 사업장은 2014년 1월 1일, 300명 미만 50 인 이상 사업장은 2015년 1월 1일, 50인 미만 사업장은 2016년 1월 1일부터 적용되었으며 업종, 직종, 단시간, 시간 제 등에 관계없이 다음의 기준에 해당되면 야간작업 특수건 강진단의 대상이 된다.

\section{야간작업 특수건강진단 대상, 주기 및 검사항목}

산업안전보건법에 따른 야간작업 특수건강진단 대상은 다음과 같다. 규칙적인 야간작업의 경우 1) 6 개월간 밤 12 시 부터 오전 5시까지의 시간을 포함하여 계속되는 8시간 작업 을 월 평균 4회 이상 수행하는 경우, 또는 2) 6개월간 오후 10 시부터 다음날 오전 6시 사이의 시간 중 작업을 월 평균 60 시간 이상 수행하는 경우이다. 불규칙적인 야간작업의 경 우에는 1) 밤 12시부터 오전 5시까지의 시간을 포함하여 계속 되는 8시간 작업을 6 개월간 누적 횟수가 24회 이상(1년 48회 이상)인 경우, 또는 2) 오후 10시부터 다음날 오전 6시 사이의 시간 중 작업을 6개월간 누적시간이 360시간 이상(1년 720시 간 이상)인 경우가 해당된다. 실시주기는 다음과 같다. 야간 작업에 종사하기 전에 실시하는 배치 전 건강진단을 받아야 하며, 배치 후 6개월 이내에 배치 후 첫 번째 건강진단을 받 게 된다. 이후에는 1 년 주기로 건강진단을 받아야 한다. 주 기가 불규칙하여 대상자 해당 여부를 판단하기 어려운 경우 에는 배치 전 건강진단은 생략하고 야간작업 종사 후 6개월 후에 야간작업 특수건강진단 대상임이 파악되면 대상임을 알게 된 월로부터 다음 월 이내에 배치 후 첫 번째 건강진단 부터 실시하게 된다.

야간작업 특수건강진단은 모든 대상자가 실시하는 1차 건 강진단이 있으며, 1 차 건강진단에서 이상이 있는 경우 받게 되는 2차 건강진단으로 나뉜다. 1차 건강진단에서는 1) 직업 력 및 노출력에 대한 조사, 2) 주요 표적기관과 관련된 병력 조사, 3) 임상검사 및 진찰을 하게 된다. 임상검사 및 진찰에 는 신경계의 불면증 증상 문진(Insomnia Severity Index), 심 혈관계의 혈압 - 혈당 - 지질 - 복부둘레, 위장관계와 내분비 계 유방암 관련 증상 문진을 실시하게 된다. 2차 건강진단에 는 신경계의 심층 면담 및 문진(Epworth Sleepiness Scale; 
$\mathrm{PSQI}$, 심혈관계의 혈압 · 혈당 · 당화혈색소 · 지질 · 24시간 심전도 및 혈압측정, 위장관계의 위내시경, 내분비계의 유방 엑스레이 및 초음파 검사를 실시하게 된다. 검사의 항목은 절대적인 것은 아니며 전문의 판단에 따라 2차 건강진단을 1 차와 함께 실시할 수 있으며 필요 시 항목에 없는 추가 정밀 검사를 실시할 수 있다.

\section{야간작업 특수건강진단 사후조치}

야간작업 특수건강진단 시행 후 각 근로자는 야간근로에 대한 업무적합성 평가결과를 받게 된다. 업무적합성 평가 구 분은 다음과 같다. 1) 가: 건강관리상 현재의 야간작업이 가 능한 경우, 2) 나: 일정한 조건(근무시간 단축, 치료를 받으면 서 근무, 작업장소 변경, 건강진단 주기 단축 등) 하에서 야 간작업이 가능한 경우, 3) 건강장해가 우려되어 한시적으로 현재의 야간작업을 할 수 없는 경우(건강상 또는 근로조건 상의 문제가 해결된 후 야간작업 복귀 가능), 4) 건강장해의 악화 또는 영구적인 장해의 발생이 우려되어 현재의 야간작 업을 해서는 안 되는 경우와 같이 근로자는 이 네 가지 분류 에 따라 사후조치 판정을 받게 된다. 야간근로의 제한 또는 단축 조치는 근로자의 실질임금과 사업주의 노무관리에 큰 영향을 미칠 수 있으므로 양측의 큰 반발에 직면할 수 있다. 따라서 담당 의사는 신중한 결정을 내려야 하며 근로자의 건 강보호를 위해 꼭 필요한 조치임을 당사자와 사업주에게 충 분히 설득시켜야 한다.

\section{야간작업 특수건강진단 결과}

특수건강진단 결과 직업병으로 판정되는 경우 직업병 유 소견자 $\left(\mathrm{D}_{1}\right)$ 로, 직업병 요관찰자에 대해서는 $\mathrm{C}_{1}$ 으로 판정하여 사후조치를 실시한다. 야간작업에 의한 건강영향은 일반 직 업병과 달리 개인적 요인과 업무상 요인이 함께 작용하여 발 병하므로, $\mathrm{D}_{1}$ 또는 $\mathrm{C}_{1}$ 이 아닌 $\mathrm{C}_{\mathrm{N}}$ 또는 $\mathrm{D}_{\mathrm{N}}$ 으로 판정하여 관 리한다. 고용노동부의 근로자 건강진단 실시결과에 따르면 2018년에 38,743개 사업장의 $1,085,856$ 명의 근로자가 야간 작업 특수건강진단을 받았으며, 그중 $33.1 \%$ 인 359,256 명이 야간작업 요관찰자 $\left(\mathrm{C}_{\mathrm{N}}\right)$ 로, $15.1 \%$ 인 163,957 명이 야간작업 유 소견자 $\left(\mathrm{D}_{\mathrm{N}}\right)$ 로 판정되었다. 야간작업 관련 질병의 요관찰자 또는 유소견자로 판정되는 경우 야간작업제한, 야간근무시 간 단축, 근무 중 치료, 추적관찰과 같은 사후관리 조치가 내 려지게 된다.

\section{교대 및 야간작업 근로금지}

「산업안전보건법 제 138 조(질병자의 근로금지 및 제한)」에 따르면 사업주는 감염병, 정신질환 또는 근로로 인하여 병세
가 크게 악화될 우려가 있는 질병으로 고용노동부령으로 정 하는 질병에 걸린 자에게는 의사의 진단에 따라 근로를 금지 하거나 제한하도록 되어 있다. `산업안전보건법 시행규칙 제 220조(질병자의 근로금지)」에 따라 정해진 질병으로는 1) 전 염될 우려가 있는 질병에 걸린 사람(전염을 예방하기 위한 조치를 행한 경우는 제외), 2) 조현병 또는 마비성 치매에 걸 린 사람, 3) 심장 또는 신장 또는 폐 등의 질환이 있는 사람으 로서 근로에 의하여 병세가 악화될 우려가 있는 사람이 해당 되며 사업주는 이 법에 따라 근로를 금지하거나 근로를 다시 시작하도록 하는 경우에는 미리 의사인 보건관리자, 산업보 건의 또는 건강진단을 실시한 의사의 의견을 듣도록 되어 있다. 또한 사업주는 근로가 금지되거나 제한된 근로자가 건 강을 회복하였을 때에는 지체 없이 근로를 할 수 있도록 하 여야 한다. 「산업안전보건법 제 132 조(건강진단에 관한 사업 주의 의무)」에 따르면 사업주는 건강진단의 결과 근로자의 건강을 유지하기 위하여 필요하다고 인정할 때에는 작업장 소 변경, 작업전환, 근로시간 단축, 야간근로의 제한, 작업환 경측정 또는 시설 설비의 설치 및 개선 등 고용노동부령으로 정하는 바에 따라 적절한 조치를 해야 하며 그 조치 결과를 고용노동부령으로 정하는 바에 따라 고용노동부장관에게 보 고해야 한다. 적절한 조치를 하지 않는 경우「산업안전보건법 제171조(벌칙)에 따라 1천만원 이하의 벌금에 처하게 된다. 따라서 사업주는 근로자의 건강유지를 위해 야간작업 특수 건강진단 결과에 따라 적절한 조치를 해야 한다. 다만 특수 건강진단기관은 사업주와의 계약을 통해 건강진단을 실시 하며, 비용 또한 사업주가 부담한다. 따라서 특수건강진단기 관과 직업환경의학과 전문의는 사업주에게 사후관리 조치를 끈질기게 설득하기 어려운 현실적인 면이 있다. 정부의 감독 과 법적인 보완을 통해 강제할 수 있는 근거가 필요한 사항 이다.

\section{야간근로의 가이드라인}

\section{직장에서의 관리}

법적인 강제조치는 아니지만 법령에서 정한 사항보다 높 은 수준의 보건 향상을 위해 정부에서는 야간근로에 대한 다 양한 가이드라인을 제공하고 있다. 각 사업장에서는 이러한 가이드라인에 따라 자율적으로 보건수준을 향상시키게 된 다. 다만 아무리 철저히 관리를 한다 해도 완벽한 야간교대 근무 시스템은 존재할 수 없으므로 최대한 야간교대근무를 수행하는 근로자 수와 야간근로시간 총량을 줄이려는 노력 이 선행되어야 할 것이다. 한국산업안전보건공단의 「교대작 업자의 보건관리지침(KOSHA GUIDE H-22-2019)」에 따 
르면 다음과 같은 상태의 근로자를 교대 및 야간근로에 배치 하고자 할 때에는 직업환경의학 전문의에게 의뢰하여 업무 가능여부에 대한 평가(업무적합성 평가)를 받은 후 배치하 도록 권고하고 있다. ${ }^{26} 1$ ) 뇌전증이 잘 조절되지 않는 근로자, 2) 불안정 협심증 또는 심근경색증 병력이 있는 관상동맥질 환자, 3) 스테로이드 치료에 의존하는 천식환자, 4) 혈당 또는 혈압이 조절되지 않는 당뇨병 또는 고혈압 환자, 5) 기관지 확장제 치료와 같이 교대작업으로 인해 약물치료가 어려운 경우, 6) 반복성 위궤양 환자, 7) 증상이 심한 과민성 대장증 후군 환자, 8) 만성 우울증 환자, 9) 교대 및 야간작업 부적응 경력이 있는 자가 여기에 해당된다.

고용노동부의「교대근로자 근로기준법 적용지침과 한국 산업안전보건공단의「교대작업자의 보건관리지침(KOSHA GUIDE H-22-2019)」에 따르면 야간근로 및 교대근무를 하 게 되는 경우 다음의 유의사항을 직장에서 고려하도록 되어 있다. 1) 교대제는 근무조가 많을수록 근로시간이 줄어들고 휴일의 기회가 많아지므로 가능하다면 2개조, 3 개조보다는 4 개조 형태인 4조 3 교대 또는 4조 2교대의 근무를 선택한다. 2) 근로시간은 1 회 8 시간과 1 주 40 시간을 준수한다. 고정적 인 상시 야간근로는 회피하며 야간근로는 연속하여 3일을 넘지 않게 한다. 3) 새벽 4 6시 또는 자정 이후와 같이 너무 빠르거나 늦은 시간대의 교대는 피한다. 4) 교대방향은 오전 반, 오후반, 야간반 순으로 정방향 순환이 되게 한다. 근무간 격은 최소 12 시간 이상을 유지하며 야간반을 끝내고 오전반 으로 들어가기 전 최소한 24시간 이상의 긴 휴식을 하도록 한다. 5) 야간반은 잠을 좀 더 잘 수 있도록 가능한 한 일찍 작업을 끝내는 등 상대적으로 짧게 실시하며 야간근로자는 주간근로자보다 연간 쉬는 날이 더 많게 조정한다. 6) 야간반 은 위험물질 노출이나 근골격계의 과도한 부담과 같은 유해 인자의 노출이 상대적으로 적도록 업무를 조정한다. 7) 원활 한 가정과 사회생활을 유지할 수 있도록 주중에 쉬는 것보다 는 주말에 쉬도록 해주며, 하루씩 띄어 쉬는 것보다는 주말에 이틀 연이어 쉬도록 하되 가능하면 일정을 계획할 때 근로 자가 원하는 바를 고려하도록 한다. 확보된 근로자의 휴가를 모두 사용할 수 있게 한다. 8) 교대일정은 근로자들이 예측할 수 있도록 미리 통보하거나 일정한 규칙이 있거나 단순한 것 이 좋다. 9) 야간근로 환경은 조도, 온도와 습도를 보다 주의 깊게 조절한다. 10) 야간근로 동안 사이잠(napping)을 자게 하며, 사이잠을 위하여 수면실을 설치하되 소음 또는 진동이 심한 곳을 피하고 성별을 구분하여 설치한다. 사이잠은 90분 이상(2 4시간 권고)이 좋으며 피로감이 가장 심한 오전 3 5 시 사이가 좋다. 11) 야간근로자에게는 칼로리는 낮고 소화가 잘 되는 양질의 음식을 규칙적으로 제공한다. 12) 야간작업
특수건강진단과 같이 야간근로자에 대해 배치 전과 정기적 으로 건강상태를 확인한다. 그 결과에 따른 사후관리를 실시 하고, 그 내용을 문서로 기록하여 보관하여 보건관리에 활용 한다. 「산업안전보건기준에 관한 규칙 제669조(직무스트레 스에 의한 건강장해 예방 조치)에 따라 야간근로자에 대해 서 정기적인 직무스트레스 요인조사와 뇌심혈관질환 발병 위험도 평가를 실시하고 그 결과에 따라 적절한 조치를 실시 한다. 13) 야간근로 배치 전에 교육과 훈련을 실시하여 근로 자가 야간근로에 대해서 잘 이해하고 적응할 수 있도록 지도 한다. 14) 가능하면 출퇴근 버스 등 교통편의를 제공하여, 이 동 중 피로를 감소시키고 출퇴근 사고를 예방한다. 15) 근로 자의 크로노타입(chronotype)을 파악하고 이를 교대근무 스 케줄 작성에 활용하면 근로자의 적응력을 높일 수 있다.

보건복지부의 「간호인력 야간근무 가이드라인」에 따르면 야간근무를 하는 간호사 및 야간전담 간호사를 대상으로 다 음의 기준을 권고하고 있다. 1) 야간근무시간은 8시간 근무를 원칙으로 함, 2) 야간전담 간호사의 경우 월 야간근무를 14일 이내로 제한, 3) 야간근무를 2일 이상 연속한 경우 48시간 이 상의 휴식을 보장, 4) 연속 야간근무는 3일 이하로 제한, 5) 야 간업무의 부담 경감을 위해 야간근무 시 업무량 조절, 6) 교 육과 훈련은 근무 종료시각에 바로 이어서 이루어지도록 배 려, 7) 근무 외의 행사참여 최소화, 8) 야간근무 인력에 대한 특수건강진단 시행, 9) 야간전담 간호사의 야간근무와 낮 근 무 전환이 가능하도록 근무선택권 보장, 10) 건강권 보호를 위해 야간전담 근무의 연속시간은 3 개월 이하로 제한하며 연장 여부를 결정하기 위해서는 개인 동의를 전제로 노사합 의에 따르도록 되어 있다.

\section{개인 생활습관 관리}

한국산업안전보건공단의 「교대작업자의 보건관리지침 (KOSHA GUIDE H-22-2019)」을 기반으로 제시하는 개인 생활습관 관리는 다음과 같다. ${ }^{26} 1$ ) 수면만을 위한 공간이 필 요하며 이 공간에서는 스마트폰이나 TV 시청 등을 하지 않 는다. 2) 빛 차단을 위해 암막 커튼을 적극 활용하고 야간근 로 후 퇴근 시 빛 차단을 위한 선글라스를 착용하며 스마트 폰은 블루라이트 조절 기능을 사용한다. 3) 취침 중 소음이 나지 않도록 가족과 이웃의 배려를 부탁한다. 야간근로자에 게 수면은 근로의 연장임을 이해시킨다. 4) 수면 공간에 온습 도계를 설치하고 쾌적한 온습도 유지를 위한 가전제품을 구 비한다. 5) 야간근로 후 가능한 한 빨리 잠자리에 들며 개인 차는 있지만 6시간 이상 연속으로 수면을 취한다. 6) 커피와 같은 카페인은 현명하게 적절한 시간대에 섭취한다. 7) 가족 과의 사회적 관계 유지도 중요하다. 가족에게 자신의 근무 
일정표를 알려주고, 가족과의 식사기회와 동료와의 취미생 활을 공유하도록 노력한다. 8) 밀린 잠의 보상을 위해 휴무인 날은 보통의 날보다 더 길게 수면을 유지(catch-up sleep)하 되 그 연장된 시간은 1 2시간 이내로 과하지 않도록 주의한 다. 9) 수면 전 과량의 식사, 커피, 음주와 운동은 회피하며 배뇨 후 잠자리에 든다. 음주는 수면제가 아니며 수면의 질을 악화시킴을 인지한다. 활동 시간대에는 수분을 충분히 섭취 한다. 10) 스트레칭, 명상과 같은 이완요법을 규칙적으로 한 다. 11) 개인적 노력으로 개선이 없는 경우 수면클리닉 등을 통해 전문의의 상담과 도움을 받는다.

\section{야간근로자의 직업병 인정}

\section{과로의 법적 기준과 직업병 인정}

$\ulcorner$ 산업재해보상보험법」은 근로자의 업무상 재해를 보상하 며, 재해 근로자의 재활 및 사회 복귀를 촉진하기 위한 법으 로 「제37조(업무상의 재해의 인정 기준)」에 따르면 업무수행 과정에서 신체에 부담을 주는 업무를 수행하여 근로자의 건 강에 장해를 미치는 경우를 업무상질병으로 인정하도록 되 어 있다. `산업재해보상보험법 시행령 [별표 3] 업무상질병에 대한 구체적인 인정기준과 「고용노동부고시 뇌혈관질병 또 는 심장질병 및 근골격계질병의 업무상질병 인정 여부 결정 에 필요한 사항」에 따르면 만성적인 과중한 업무를 수행한 것이 객관적으로 확인되는 경우 뇌혈관 또는 심장질병을 업 무상질병으로 인정하고 있다.

만성적인 과중한 업무의 기준은 보통 주당 근무시간이 중 요한 근거가 되며, 발병 전 4주 동안 1주 평균 64시간 또는 발병 전 12 주 동안 1 주 평균 60 시간 이상인 경우 관련성이 높다고 판단한다. 하지만 이 시간에 어느 정도 미달되더라도 교대근무를 시행한 경우 가중요인을 인정하며, 오후 10시부 터 다음날 오전 6시까지의 야간근로에 대해서는 $30 \%$ 의 근무 시간을 가산해 준다. 다만「근로기준법 제63조(적용의 제외), 근로기준법 시행규칙 제 10 조(근로시간 등의 적용제외 승인 신청 등 에 따라 경비직 등 감시 및 단속 업무이거나 이와 유 사한 업무인 경우 업무시간을 가중하지 않는다. 시간가중은 하지 않지만, 근무지와 별개로 독립된 장소에서의 수면시간 은 충분히 제공되어야 한다. 이러한 독립된 장소는 수면방해 를 받지 않을 정도로 소음, 빛과 외부간섭이 차단되어야 하 며, 이러한 독립된 장소에서 연속 5시간 이상 수면시간이 제 공되지 않는 경우에는 업무시간으로 산입하도록 되어 있다. 아파트 단지의 경비직과 같은 감시업무에 야간근로를 실시 하는 고령근로자의 비율이 높다. 고령근로자는 이러한 뇌심 혈관질환에 더욱 취약할 수밖에 없으므로, 고령자를 야간근
로에 배치하기 전에는 배치 전 건강진단을 통해 건강을 면밀 히 평가한 후 업무를 시작하게 해야 할 것이다. 고령근로자의 야간근로의 경우 뇌심혈관질환의 위험요소인 겨울철 실외 작업과 같은 한랭작업과 여름철 고열작업에 대한 적절한 관 리도 고려되어야 한다.

\section{교대근무자 정신질환의 직업병 인정}

법령상으로는 야간근로에 대한 정신질환 인정에 대한 명 문화된 기준은 현재 없다. 다만 대법원의 판결 등에서 장기간 교대근무를 실시한 근로자에게 발생한 수면장애와 불안장 애를 업무상질병으로 인정한 사례가 있어 향후 이에 대한 사 회적 합의 수준 도출을 위한 연구가 필요할 것으로 판단된다.

\section{암의 직업병 인정}

덴마크에서는 야간근로를 주당 1 회 이상, 25 년 이상 수행한 여성근로자에서 유전적 소인과 같은 개인요인이 없는 경우, 유방암을 업무상질병으로 인정하고 있다. 영국에서는 20년 이상 장기간 근무 시 유방암의 위험도 증가 가능성을 제시하 고 있으나, 직업병 목록에 넣기에는 아직 근거가 불충분하다 는 판단이다. 우리나라에서도 정해진 기준은 없으나 덴마크 의 기준을 인용하여 야간작업 25년 이상이거나, 이보다 짧더 라도 다른 발암요인에 복합적으로 노출되는 경우 인정을 하 는 방향으로 현재 의학적, 사회적 합의가 진행중이다. ${ }^{56,57}$

\section{결 론}

야간근로를 수행하게 되는 근로자의 약 $10 \%$ 가량만이 업 무에 잘 적응하며, $20 \%$ 는 적응하지 못하고 결국 직장을 그만 두게 되고, 나머지 대다수 근로자는 힘들지만 참고 밤에 일 하게 된다. 천하장사도 들지 못하는 것이 무거운 눈꺼풀이 라는 말이 있으며, 인간이 야간근로에 완전히 적응하기는 사 실상 불가능하다. 인간은 지구에 태어날 때 모두 생체시계 하나를 가지고 태어나며, 이 생체시계는 지구의 시계와 일치 할 때 가장 자연스럽다. 야간근로와 교대제로 인한 근로자 피해를 최소화하기 위한 다양한 교대제 패턴이 개발되고 환 경이 개선되었다. 하지만 건강피해가 전혀 없는 완벽한 야간 근로 시스템은 존재할 수 없다. 매 앞에 장사 없듯이, 야간근 로 앞에도 장사는 없다. 사회적으로 불필요한 야간근로를 최 대한 줄이려는 합의와 노력이 필요하다. 불가피한 야간근로 자를 대상으로는 건강보호를 위해 야간근로의 개수와 시간 을 줄여 덜 나쁜 야간근로를 하게 해야 하며, 충분한 보상도 이루어져야 할 것이다. 야간근로가 무제한 가능한 보건업과 같은 특례업종에 대한 근로기준법의 예외규정 존치에 대해 
서도 향후 논의되어야 할 것이며, 근로자와 국민의 건강보호 를 위해 현재의 야간근로 관련 법규들을 좀 더 세심하고 정 교하게 보완해 나가야 할 것이다. 그리고 잘 만들어진 법규 들도 유명무실해지지 않도록 정부의 체계적인 관리감독이 필수적이다. 이것이 우리나라 노동환경의 만성적인 문제인 높은 산재사망률, 실업률, 장시간 근로와 낮은 노동생산성 해결의 실마리가 될 수 있다.

\section{Acknowledgments}

None.

\section{Conflicts of Interest}

The author has no potential conflicts of interest to disclose.

\section{ORCID iD}

Won-Ju Park https://orcid.org/0000-0002-1081-9840

\section{REFERENCES}

1. Ministry of Employment and Labor. Explanation (Q\&A) and guidelines for special health checkups for night work. 2014 Jan [cited 2020 Dec 22]. URL:http://www.moel.go.kr/news/notice/noticeView. do?bbs_seq $=1389170242858$.

2. Ministry of Employment and Labor. Management plan for workers who perform heavy work such as overtime, night, and holiday work. 2011 Sep [cited 2020 Dec 22]. URL:http://www.prism.go.kr/homepage/entire/retrieveEntireDetail.do?pageIndex =1\&research $\mathrm{id}=1490000-201100096 \&$ leftMenuLevel=160\&cond_research_ name $=\%$ EC $\% 95 \%$ BC\%EA \% B 0\%84\&cond_research_start_ date $=\&$ cond_research_end_date $=\&$ pageUnit $=10 \&$ cond_order $=3$.

3. International Agency for Research on Cancer (IARC). Night shift work. IARC Monogr Identif Carcinog Hazards Hum 2020;124:1-371.

4. Harrington JM. Shift work and health--a critical review of the literature on working hours. Ann Acad Med Singap 1994;23:699-705.

5. Vyas MV, Garg AX, Iansavichus AV, et al. Shift work and vascular events: systematic review and meta-analysis. BMJ 2012;345:e4800. https://doi.org/10.1136/bmj.e4800.

6. Kang W, Park WJ, Jang KH, et al. Coronary artery atherosclerosis associated with shift work in chemical plant workers by using coronary CT angiography. Occup Environ Med 2016;73:501-505. https://doi. org/10.1136/oemed-2015-103118.

7. Brown DL, Feskanich D, Sánchez BN, Rexrode KM, Schernhammer ES, Lisabeth LD. Rotating night shift work and the risk of ischemic stroke. Am J Epidemiol 2009;169:1370-1377. https://doi.org/10.1093/ aje/kwp056

8. Li M, Huang JT, Tan Y, Yang BP, Tang ZY. Shift work and risk of stroke: a meta-analysis. Int J Cardiol 2016;214:370-373. https://doi.org/10.1016/ j.ijcard.2016.03.052.

9. Gan Y, Yang C, Tong X, et al. Shift work and diabetes mellitus: a metaanalysis of observational studies. Occup Environ Med 2015;72:72-78. https://doi.org/10.1136/oemed-2014-102150.

10. Pan A, Schernhammer ES, Sun Q, Hu FB. Rotating night shift work and risk of type 2 diabetes: two prospective cohort studies in women. PLoS Med 2011;8:e1001141. https://doi.org/10.1371/journal.pmed.1001141.

11. Park J, Shin SY, Kang Y, Rhie J. Effect of night shift work on the control of hypertension and diabetes in workers taking medication. Ann Occup Environ Med 2019;31:e27. https://doi.org/10.35371/aoem.2019.31.e27.

12. Wang F, Zhang L, Zhang Y, et al. Meta-analysis on night shift work and risk of metabolic syndrome. Obes Rev 2014;15:709-720. https://doi. org/10.1111/obr.12194.
13. Pietroiusti A, Neri A, Somma G, et al. Incidence of metabolic syndrome among night-shift healthcare workers. Occup Environ Med 2010;67:5457. https://doi.org/10.1136/oem.2009.046797.

14. Sun M, Feng W, Wang F, et al. Meta-analysis on shift work and risks of specific obesity types. Obes Rev 2018;19:28-40. https://doi.org/10.1111/ obr.12621

15. Antunes LC, Levandovski R, Dantas G, Caumo W, Hidalgo MP. Obesity and shift work: chronobiological aspects. Nutr Res Rev 2010;23: 155-168. https://doi.org/10.1017/S0954422410000016.

16. Akerstedt T. Shift work and disturbed sleep/wakefulness. Sleep Med Rev 1998;2:117-128. https://doi.org/10.1016/s1087-0792(98)90004-1.

17. Akerstedt T, Knutsson A, Westerholm P, Theorell T, Alfredsson L, Kecklund G. Work organisation and unintentional sleep: results from the WOLF study. Occup Environ Med 2002;59:595-600. https://doi.org/ 10.1136/oem.59.9.595.

18. Cruz C, Della Rocco P, Hackworth C. Effects of quick rotating shift schedules on the health and adjustment of air traffic controllers. Aviat Space Environ Med 2000;71:400-407.

19. Akerstedt T, Fredlund P, Gillberg M, Jansson B. A prospective study of fatal occupational accidents -- relationship to sleeping difficulties and occupational factors. J Sleep Res 2002;11:69-71. https://doi.org/10.1046/ j.1365-2869.2002.00287.x.

20. Dembe AE, Erickson JB, Delbos RG, Banks SM. Nonstandard shift schedules and the risk of job-related injuries. Scand J Work Environ Health 2006;32:232-240. https://doi.org/10.5271/sjweh.1004.

21. Fransen M, Wilsmore B, Winstanley J, et al. Shift work and work injury in the New Zealand Blood Donors' Health Study. Occup Environ Med 2006;63:352-358. https://doi.org/10.1136/oem.2005.024398.

22. Wong IS, McLeod CB, Demers PA. Shift work trends and risk of work injury among Canadian workers. Scand J Work Environ Health 2011; 37:54-61. https://doi.org/10.5271/sjweh.3124.

23. Wagstaff AS, Sigstad Lie JA. Shift and night work and long working hours--a systematic review of safety implications. Scand J Work Environ Health 2011;37:173-185. https://doi.org/10.5271/sjweh.3146.

24. Gold DR, Rogacz S, Bock N, et al. Rotating shift work, sleep, and accidents related to sleepiness in hospital nurses. Am J Public Health 1992; 82:1011-1014. https://doi.org/10.2105/ajph.82.7.1011.

25. Scott LD, Hwang WT, Rogers AE, Nysse T, Dean GE, Dinges DF. The relationship between nurse work schedules, sleep duration, and drowsy driving. Sleep 2007;30:1801-1807. https://doi.org/10.1093/ sleep/30.12.1801.

26. Korea Occupational Safety Health Agency (KOSHA). Health management guidelines for shift workers. Ulsan: KOSHA; 2019 Oct. 5 p. Report No.: KOSHA GUIDE H-22-2019.

27. Knutsson A, Bøggild H. Gastrointestinal disorders among shift workers. Scand J Work Environ Health 2010;36:85-95. https://doi.org/10.5271/ sjweh. 2897.

28. Segawa K, Nakazawa S, Tsukamoto Y, et al. Peptic ulcer is prevalent among shift workers. Dig Dis Sci 1987;32:449-453. https://doi.org/ 10.1007/BF01296025.

29. Nojkov B, Rubenstein JH, Chey WD, Hoogerwerf WA. The impact of rotating shift work on the prevalence of irritable bowel syndrome in nurses. Am J Gastroenterol 2010;105:842-847. https://doi.org/10.1038/ ajg.2010.48.

30. Chung TH, Lee J, Kim MC. Impact of night-shift work on the prevalence of erosive esophagitis in shipyard male workers. Int Arch Occup Environ Health 2016;89:961-966. https://doi.org/10.1007/s00420-0161130-x.

31. Pietroiusti A, Forlini A, Magrini A, et al. Shift work increases the frequency of duodenal ulcer in H pylori infected workers. Occup Environ Med 2006;63:773-775. https://doi.org/10.1136/oem.2006.027367.

32. Harrington JM. Health effects of shift work and extended hours of work. Occup Environ Med 2001;58:68-72. https://doi.org/10.1136/ oem.58.1.68.

33. Sallinen M, Härmä M, Mutanen P, Ranta R, Virkkala J, Müller K. 
Sleep-wake rhythm in an irregular shift system. J Sleep Res 2003;12: 103-112. https://doi.org/10.1046/j.1365-2869.2003.00346.x.

34. Choi SJ, Park HR, Joo EY. Effects of light on daytime sleep in 12 hours night shift workers: a field study. J Sleep Med 2019;16:26-35. https:// doi.org/10.13078/jsm.19026.

35. Son M, Kong JO, Koh SB, Kim J, Härmä M. Effects of long working hours and the night shift on severe sleepiness among workers with 12hour shift systems for 5 to 7 consecutive days in the automobile factories of Korea. J Sleep Res 2008;17:385-394. https://doi.org/10.1111/ j.1365-2869.2008.00675.x.

36. Chan OY, Gan SL, Yeo MH. Study on the health of female electronics workers on 12 hour shifts. Occup Med (Lond) 1993;43:143-148. https:// doi.org/10.1093/occmed/43.3.143.

37. Paciorek M, Korczyński P, Bielicki P, Byśkiniewicz K, Zieliński J, Chazan R. Obstructive sleep apnea in shift workers. Sleep Med 2011;12: 274-277. https://doi.org/10.1016/j.sleep.2010.06.013.

38. Kamdar BB, Tergas AI, Mateen FJ, Bhayani NH, Oh J. Night-shift work and risk of breast cancer: a systematic review and meta-analysis. Breast Cancer Res Treat 2013;138:291-301. https://doi.org/10.1007/ s10549-013-2433-1.

39. Wang F, Yeung KL, Chan WC, et al. A meta-analysis on dose-response relationship between night shift work and the risk of breast cancer. Ann Oncol 2013;24:2724-2732. https://doi.org/10.1093/annonc/mdt283.

40. Cordina-Duverger E, Menegaux F, Popa A, et al. Night shift work and breast cancer: a pooled analysis of population-based case-control studies with complete work history. Eur J Epidemiol 2018;33:369-379. https://doi.org/10.1007/s10654-018-0368-x.

41. Cho S, Park WJ, Kang W, Lim DY, Kim S, Moon JD. Night shiftwork and prostate-specific antigen level in a tire manufacturing factory. Ann Occup Environ Med 2019;31:e19. https://doi.org/10.35371/aoem.2019.31.e19.

42. Parent MÉ, El-Zein M, Rousseau MC, Pintos J, Siemiatycki J. Night work and the risk of cancer among men. Am J Epidemiol 2012;176:751-759. https://doi.org/10.1093/aje/kws318.

43. Papantoniou K, Devore EE, Massa J, et al. Rotating night shift work and colorectal cancer risk in the nurses' health studies. Int J Cancer 2018; 143:2709-2717. https://doi.org/10.1002/ijc.31655.

44. Wang X, Ji A, Zhu Y, et al. A meta-analysis including dose-response relationship between night shift work and the risk of colorectal cancer. Oncotarget 2015;6:25046-25060. https://doi.org/10.18632/oncotarget.4502.

45. Woo JM, Postolache TT. The impact of work environment on mood disorders and suicide: evidence and implications. Int J Disabil Hum
Dev 2008;7:185-200. https://doi.org/10.1515/ijdhd.2008.7.2.185

46. Scott AJ, Monk TH, Brink LL. Shiftwork as a risk factor for depression: a pilot study. Int J Occup Environ Health 1997;3:S2-S9.

47. Driesen K, Jansen NW, Kant I, Mohren DC, van Amelsvoort LG. Depressed mood in the working population: associations with work schedules and working hours. Chronobiol Int 2010;27:1062-1079. https://doi.org/10.3109/07420528.2010.489877.

48. Ruggiero JS. Correlates of fatigue in critical care nurses. Res Nurs Health 2003;26:434-444. https://doi.org/10.1002/nur.10106.

49. Bara AC, Arber S. Working shifts and mental health--findings from the British Household Panel Survey (1995-2005). Scand J Work Environ Health 2009;35:361-367. https://doi.org/10.5271/sjweh.1344.

50. Lin PC, Chen CH, Pan SM, et al. Atypical work schedules are associated with poor sleep quality and mental health in Taiwan female nurses. Int Arch Occup Environ Health 2012;85:877-884. https://doi.org/10.1007/ s00420-011-0730-8.

51. Kang W, Jang KH, Lim HM, Ahn JS, Park WJ. The menstrual cycle associated with insomnia in newly employed nurses performing shift work: a 12-month follow-up study. Int Arch Occup Environ Health 2019;92:227-235. https://doi.org/10.1007/s00420-018-1371-y.

52. International Labour Organization (ILO). C171 - Night Work Convention, 1990 (No. 171). 1990 Jun [cited 2020 Dec 22]. URL:https:// www.ilo.org/dyn/normlex/en/f?p=NORMLEXPUB:12100:0::NO: :P12100_ILO_CODE:C171.

53. Sadamatsu M, Kato N, lida H, et al. The 24-hour rhythms in plasma growth hormone, prolactin and thyroid stimulating hormone: effect of sleep deprivation. J Neuroendocrinol 1995;7:597-606. https://doi.org/ 10.1111/j.1365-2826.1995.tb00797.x.

54. Ministry of Employment and Labor. Analysis of industrial accidents 2018. 2019 Dec [cited 2020 Dec 22]. URL:http://www.moel.go.kr/policy/policydata/view.do?bbs_seq=20191200830.

55. Korea Institute for Health and Social Affairs (KIHASA). Policy challenges for preventing and compensating overwork-related death. [cited 2020 Dec 22]. URL:https://www.kihasa.re.kr/web/publication/periodi$\mathrm{cal} /$ view $\cdot$ do menuId $=48 \&$ tid $=38 \&$ bid $=19 \&$ aid $=426 \&$ ano $=8$.

56. Ministry of Employment and Labor. Research on specific exposure levels of occupational cancer hazardous substances. Sejong: Ministry of Employment and Labor; 2015 Dec. 115 p. Report No.: 11-1492000000372-01.

57. Lee HE, Lee J, Jang TW, Kim IA, Park J, Song J. The relationship between night work and breast cancer. Ann Occup Environ Med 2018;30: 11. https://doi.org/10.1186/s40557-018-0221-4. 